\title{
Uses for Incomplete Ammonite Sutures: Lateral Lobe and Second Saddle as Markers of Sutural Complexity
}

\author{
Katherine Marriott ${ }^{1, *}$ and John A. Chamberlain, Jr. ${ }^{1,2}$ (D) \\ 1 Department of Earth and Environmental Sciences, Brooklyn College, Brooklyn, NY 11210, USA; \\ johnc@brooklyn.cuny.edu \\ 2 PhD Programs in Earth and Environmental Sciences, and in Biology, Graduate Center, \\ City University of New York, New York, NY 10016, USA \\ * Correspondence: katelomedicomarriott@gmail.com; Tel.: +1-(845)-264-4728
}

Citation: Marriott, K.; Chamberlain, J.A., Jr. Uses for Incomplete Ammonite Sutures: Lateral Lobe and Second Saddle as Markers of Sutural Complexity. Geosciences 2021, 11, 476. https://doi.org/10.3390/geosciences 11110476

Academic Editors: Angelos

G. Maravelis and

Jesus Martinez-Frias

Received: 21 September 2021

Accepted: 16 November 2021

Published: 19 November 2021

Publisher's Note: MDPI stays neutral with regard to jurisdictional claims in published maps and institutional affiliations.

Copyright: (c) 2021 by the authors. Licensee MDPI, Basel, Switzerland. This article is an open access article distributed under the terms and conditions of the Creative Commons Attribution (CC BY) license (https:// creativecommons.org/licenses/by/ $4.0 /)$.

\begin{abstract}
Ammonoid sutures are geometric patterns formed by the intersection of the septa and the shell wall, and have long been a diagnostic tool for ammonite researchers for such applications as species identification, taxonomic relationships, ontogenetic change, functional and evolutionary morphology, determination of ecological niche, and other aspects of ammonoid paleobiology. Researchers interested in a variety of paleobiological questions related to ammonoids have almost always required access to the entire hemisuture. Without access to specimens in museum or institutional collections, researchers must rely on previously published illustrations and photographs of ammonoid sutures. However, due to the perspective in photographs, distortion of the marginal elements of suture geometry occurs due to shell curvature near the venter and umbilicus when photographed in profile. The revised approach described here, which we refer to as the Lateral Lobe Saddle, or LLS approach, makes use of only the lateral lobe and second saddle $\mathrm{S}_{2}$ (lateral lobe-second saddle pairs, or LLS) which lie in the central, mid-whorl undistorted sector of a suture line as viewed in lateral, profile shell photos and illustrations. The factors by which fractal dimension of LLS data convert to fractal dimension of the standard hemisuture measurements are largely consistent within genera. The LLS method's non-requirement of a full hemisuture also facilitates comparisons among sutures within an ontogenetic sequence, or sutures from multiple ammonite taxa where ventral and umbilical sutural elements are hidden by whorl overlap or poor preservation.
\end{abstract}

Keywords: ammonite; sutures; fractal geometry; ammonoid paleobiology; functional morphology; ontogeny

\section{Introduction}

Ectocochleate cephalopods have many-chambered shells. The septal walls between chambers increased in their complexity over evolutionary time, and the high complexity of Mesozoic ammonite sutures in particular has puzzled researchers for almost two centuries [1]. Ammonoid suture complexity is an amalgamation of the degree of infolding of the suture, and the geometric arrangement of these folds [2]. Suture geometry, the underlying premise of suture complexity, has potentially significant but not completely understood implications for ammonoid paleobiology, including habitat preferences, differences in septal function, phylogeny, and ontogeny.

Studies of suture complexity have a long and complicated history. An early method to account for septal complexity was first described by Westermann [2] which resulted in the Index of Sutural Complexity (ISC) as the distance measured along a full hemisuture compared to the distance measured along a straight line between the end points of the hemisuture. Shortly thereafter, Mandelbrot's equations [3] were applied to ammonoid suture complexity, as suture patterns can be viewed as self-similar entities approximating fractals [4-18] (Figure 1). True fractals are mathematical constructs in which an infinite number of subdivisions can occur on an object, such that each subdivision is a perfect 
identical miniature of the greater whole [3,9-14]. Fourier transforms have also been applied to issues of sutural complexity, such as by Hariri and Bachnou [19]. However, Lutz and Boyajian [10] observed that while the ISC works well for goniatites and Ceratites, Jurassic and Cretaceous ammonites more clearly exhibit fractal self-similarity than earlier ectocochleates to which Ward [4] also applied his ISC. They argued, therefore, that expressing ammonitic suture complexity in fractal form is the simplest, most reliable method, and the method to be preferred for the highly complex sutures of Ammonitida. The approach in the fractal analysis of ammonite sutures has been appropriated and modified from shoreline measurement [20], and can be applied to the quantification of any uneven natural surface or edge which sufficiently resembles the fractal property of self-similarity $[3,9-13,15]$.
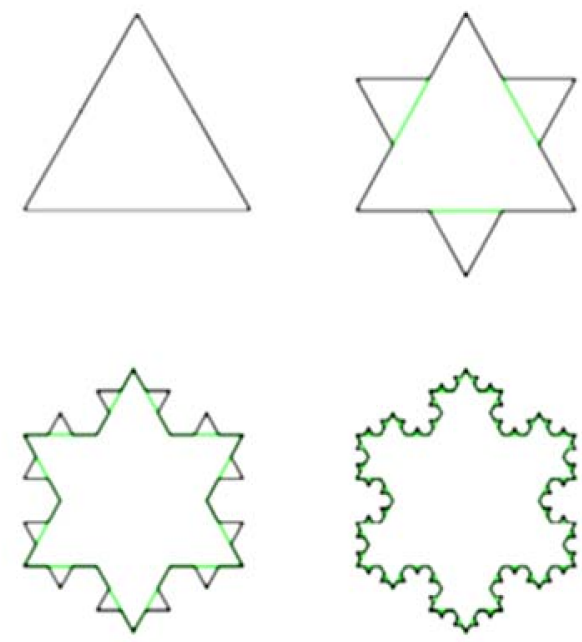

Figure 1. A representation of the Koch Snowflake showing the principle of fractal self-similarity. The triangular divisions are perfectly proportional to one another and continue into infinity. Modified from WXS, Wikimedia Commons.

Usually, complexity of ammonite suture is expressed as a fractal dimension based on half a suture, or hemisuture, whose bounds are the center of the external lobe (E) to and distalmost umbilical lobe (typically labelled $\mathrm{U}_{1}$ ). Complexity can be calculated from hemisuture tracings that have already been published. While reliance on pre-published hemisutures continues to be useful, strict reliance on only these published data presents limitations to researchers who are unable to access all the ammonite specimens they need in person. We have inserted a revision into the most commonly used fractal equation to address four principal limitations to the existing method. Our modification may eliminate the need for researchers to visit some far-away collections to measure ammonite sutures by enabling data to be shared between colleagues from photographs.

The present body of published ammonite sutures does not include every species, and includes even fewer ontogenetic sequences.

a. The modified method offers a new way to take a full ontogeny of sutures from just one shell, rather than compositing data from many shells.

b. For broad-scale analyses, our modification widens the potential sample size by enabling the use of specimens broken or crushed during post-mortem compaction.

\section{Materials}

Ammonite sutures were collected from tracings in existing publications and account for the bulk of specimens in this study. These include Reeside [21], Cobban [22-25], Schindewolf [26-28], Cobban and Jeletsky [29], Kullmann and Wiedmann [30], Schlegelmilch [31,32], Stevens [33], Lominazde and Saharikazde [34], Kennedy and Cobban [35], Kennedy et al. [36], Shevyrev [37], Joly [38], Hoffmann [39], Ifrim et al. [40], Galácz and Kassai [41], 
Dias-Canas and Patarroyo [42], and Hoffmann and Maisch [43]. The specimens included are Jurassic and Cretaceous ammonites. The sutures were copied and then traced using both the Richardson Step Method and LLS-Modified Step Method by hand on Gimp, an open-source software mimicking Adobe Photoshop. All statistical analyses were performed in PAST Paleontological Statistics Software [44]. Where applicable, additional partial sutures came from ammonite specimens photographed in profile. Photographs were sourced from the research collection of Rene Hoffmann at Ruhr-Universität Bochum, the digital catalogues of Musee National d'Histoire Naturelle in Paris, and the Paleontological Research Institution's Digital Atlas of Ancient Life.

\section{Methods}

There are a variety of approaches that can be used to calculate a structure's fractal dimension [13,14]. All require the selection of a unit of length (rule size) used to measure the structure.

a. The Richardson Step Method. The Richardson Step Method, described by [10], is one such approach that has been widely applied to ammonite sutures $[9,10,13,15,16]$. In this approach, rule size can be expressed in terms of actual mensuration units (e.g., 5, 10 , or $20 \mathrm{~mm}$ ), or alternatively as fractions of the straight-line distance $\left(L_{\max }\right)$ between the ends of the hemisuture (e.g., $1 / 5,1 / 10$, or $1 / 20$ of the total straight-line distance from the external to the umbilical lobe) (Figure 2).

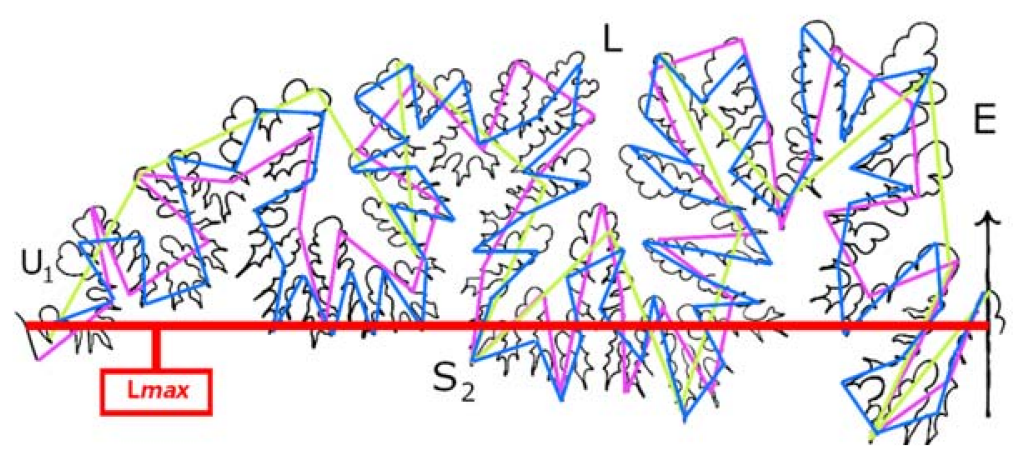

Figure 2. Step count of Eogaudryceras numidum suture using the Richardson Step Method as described by $[13,14]$ using fractions of the hemisuture length $\left(L_{\max }\right)$ as rule sizes. Green is $1 / 5$, magenta is $1 / 10$, and blue is 1/15. Eogaudryceras numidum suture redrawn by KM from Figure 31E in [39].

To evaluate a suture using the Richardson approach, one first adopts a rule size, e.g., $1 / 5$ the end-to-end straight-line distance $\left(L_{\max }\right)$. Beginning at the point representing the center of the external lobe, which we take as one end point of the hemisuture, one pivots the ruler until the $1 / 5$ measure on the ruler intersects the suture line. This is the first step. The second step begins at the end point of the first step. The ruler is again pivoted until it intersects the suture a second time. The full hemisuture from $\mathrm{E}$ to $\mathrm{U}_{1}$ is measured by repeating this process until the $U_{i}$ lobe is reached. The number of whole steps for the suture are then totaled. Partial steps, which can occur if the last step is not completed, are not included in the final count. For the Richardson Method, the authors of [10] indicate that a hemisuture's fractal dimension can be calculated from the following equation (Equation (2) of [13]).

$$
D f=\frac{\log N}{\log \left(\frac{1}{L}\right)}
$$

where $N$ is the step count, $L$ is the rule size, and $D f$ is the fractal dimension.

b. The LLS Step Method. In contrast to the Richardson Method, our LLS Method measures only the lateral lobe and the second saddle $\left(\mathrm{S}_{2}\right)$ (Figures 3 and 4 ). In the LLS Step Method, rule size is equal to a given fraction of $L_{\max }$, which for LLS is the length 
between the top of the lateral lobe (L) and the base of $S_{2}$ (e.g., 1/5, 1/10,1/20 of this distance). We do not use actual mensuration units (e.g., $5 \mathrm{~mm}, 10 \mathrm{~mm}, 20 \mathrm{~mm}$ ). In Figure 3, the magenta line is the full length of the maximum length from which rule sizes can be drawn, $L_{\max }$, and the green line shows a rule size of $1 / 10$ the length of the lateral lobe-saddle pair. One-tenth hemisuture lengths were used by [10] in their study of ammonite sutures.

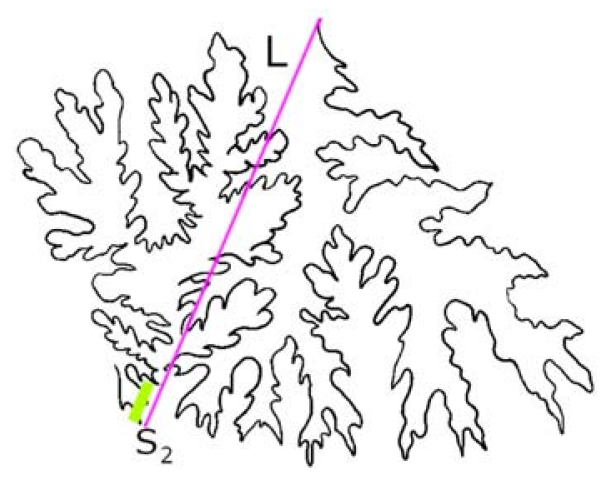

Figure 3. A lateral lobe-saddle pair of Lytoceras taharoaense, the rule size (green) is one-tenth the distance $L_{\max }$ (magenta) from the base of the lateral lobe (L) to that of $\mathrm{S}_{2}$. Redrawn by KM from Figure 23 in [33].

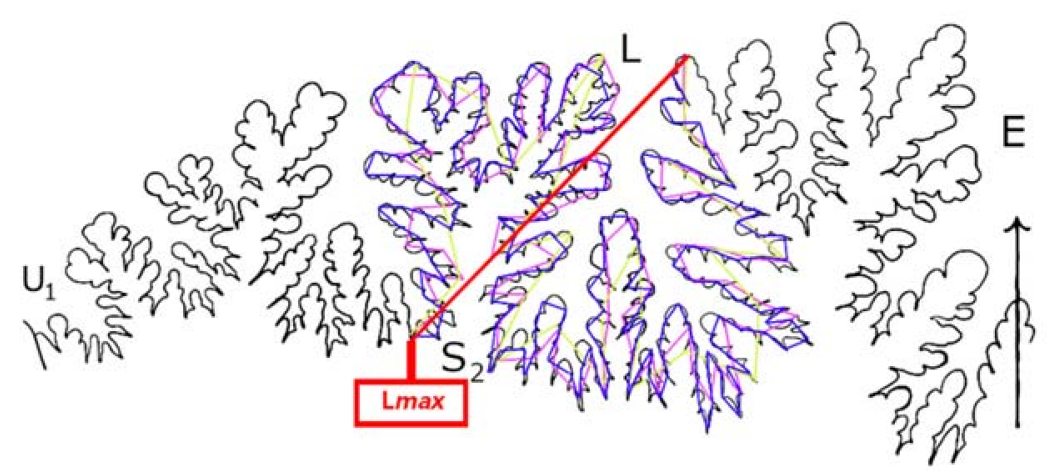

Figure 4. Step count of Eogaudryceras numidum suture using the LLS Method as described using fractions of the LLS length $\left(L_{\max }\right)$ as rule sizes. Green is $1 / 5$, magenta is $1 / 10$, and blue is $1 / 15$. Eogaudryceras numidum suture redrawn by KM from Figure 31E in [39].

The definitions of rule size and $L_{\max }$ were modified to include only fractions of the span between the base of the lateral lobe $(\mathrm{L})$ and the second saddle $\left(\mathrm{S}_{2}\right)$ adjoining the lateral lobe's umbilical side (Figure 4). This restricts the study area to only the nearly flat section of the hemisuture in most photos and allows the portion of a suture with only minimal distortion to be used. This is because doing so eliminates the umbilical and ventral lobes and saddles, which become distorted as sutures on an ammonite surface curve downward near the venter and umbilicus. This lateral lobe-saddle pair approach enables photographic evidence to be included in suture research where the whole hemisuture is unusable, and can also eliminate challenges with partial preservation. It also promotes the study of suture ontogeny because the terminal portions of a suture, usually hidden due to whorl overlap, are not needed in the analysis.

\section{c. Conversion of LLS Data to Richardson Data.}

Because steps are based on fractions of the LLS distance ( $L_{\max }$ in Figure 4$)$, which is considerably smaller than the end-to-end straight-line distance for the hemisuture containing that lobe-saddle pair ( $L_{\max }$ in Figure 2 ), steps for a given rule size, e.g., $1 / 10 \mathrm{~L}$ vs. $1 / 10 L_{\max }$, are smaller in the LLS Method compared to the Richardson Method. This means that for a 
given rule size, the LLS Method will produce different, usually higher, step counts than the Richardson Method. Likewise, Equation (1) will thus yield different, usually higher, fractal values for a given lateral lobe-saddle pair than for the full hemisuture containing this lobe-saddle pair measured using the Richardson Method. For individual genera, the factors by which this is possible are largely consistent (Figure 5), indicating that specific and predictable values are required for the conversion of most members of a given ammonite genus. These factors can be determined by Equation (2A):

$$
V=N_{L L S} / N_{R}
$$

where $V$ is the conversion value, $N_{L L S}$ is the LLS step count, and $N_{R}$ is the Richardson step count.

Table 1. Comparison of results for calculating the fractal dimension of three different ammonite suture lines from File S1 (in the Supplementary Materials for this manuscript) using the Richardson and LLS step Methods. Step length $=1 / 15$ appropriate base line distance in each case. $N=$ number of steps; $D f=$ fractal dimension of suture line; $V=$ conversion value needed to make the LLS $D f=$ Richardson $D f$. Suture A is from a shell of the genus Lytoceras, Suture B is from a shell of the genus Perisphinctes, and Suture $\mathrm{C}$ is from a shell of the genus Harpoceras.

\begin{tabular}{cccccccc}
\hline & \multicolumn{2}{c}{$\begin{array}{c}\text { SUTURE A } \\
\text { Lytoceras sp. }\end{array}$} & \multicolumn{2}{c}{$\begin{array}{c}\text { SUTURE B } \\
\text { Perisphinctes sp. }\end{array}$} & \multicolumn{2}{c}{$\begin{array}{c}\text { SUTURE C } \\
\text { Harpoceras sp. }\end{array}$} \\
\cline { 2 - 9 } & Richardson & LLS & Richardson & LLS & Richardson & LLS \\
\hline N & 98 & 144 & 47 & 91 & 40 & 54 \\
Df & 1.921 & 2.088 & 1.602 & 1.916 & 1.532 & 1.682 \\
V & & 1.469 & & & 1.936 & & \multicolumn{2}{c}{1.350} & \\
\hline
\end{tabular}

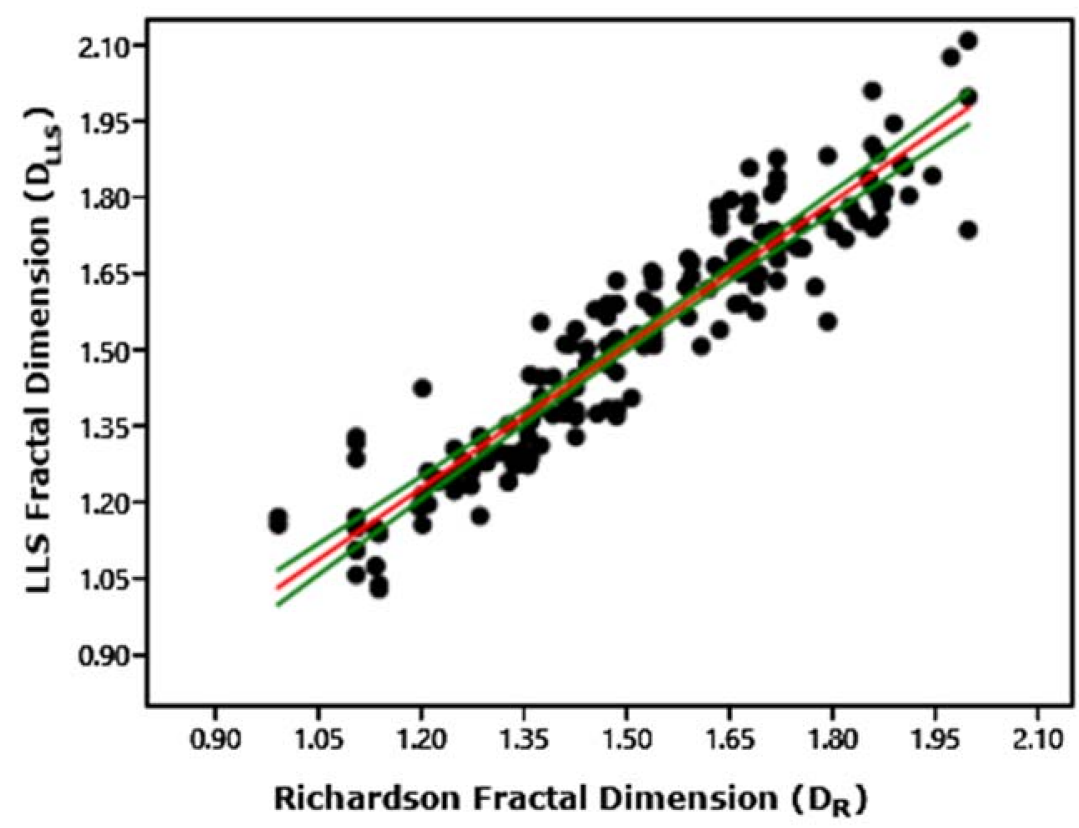

Figure 5. A least-squares plot of the fractal dimensions of ammonite hemisutures versus lateral lobe-saddle pairs using the appropriate conversion values from Table 1, using the program PAST [44]. $r^{2}=0.88143$ for all genera together. The green lines are bootstrapped $95 \%$ confidence limits.

The fractal equation can therefore be adjusted to reflect this conversion of LLS data into Richardson-equivalent data. This modification is needed for LLS data to be useful in 
comparison to existing fractal data for ammonite sutures. Equation (2B) shows the required modification to the existing equation:

$$
D f_{R}=\log \left(N_{L L S} / V\right) / \log (1 / L)
$$

where $N_{L L S}$ is the number of steps recorded using the LLS Method, $L$ is the rule size (or divisor of $\left.L_{\max }\right), D f_{R}$ is the fractal dimension as expressed in the Richardson Method, and $V$ is the conversion value. Table 1 compares such an alternate way of calculating the conversion, using the same results for a few representative ammonite suture lines.

\section{Results and Discussion}

a. Taxonomic Implications of the Richardson/LLS Conversion Value:

It is of interest here to evaluate the relationship between results from the two approaches more fully because suture geometry has historically been considered a diagnostic tool when assigning taxonomy to an ammonite [23-25,30]. Our approach is to evaluate conversion values for a large number of sutures taken from species within selected genera of Jurassic and Cretaceous ammonites. We performed this from a minimum of 10 fractal measurements of sutures from each genus (but 24 to 60 sutures for most genera). Each suture was evaluated using both the Richardson and LLS Methods, and at step lengths of $1 / 5,1 / 10$, and usually also $1 / 15$ of $L_{\max }$ from both the hemisuture and LLS. The general geometry of sutures, more than the number of subdivisions, appears to be the driving force behind the variation in conversion values across taxa. It does not appear that complexity alone (expressed as a fractal dimension) is a primary driver behind the conversion value that must be assigned to a given ammonite genus. While most of the highest conversion values were taken from highly complex ammonite sutures, sutures exhibiting low complexity also occasionally had high conversion values, as in the case of Placenticeras (Supplementary Materials), and vice versa in the case of some of our data for Pachydiscus.

We found that within most genera that we sampled, species show roughly equivalent conversion values. Table 2 shows this for one such representative genus. The data in Table 2 indicate that sutures of congeneric species have roughly equivalent complexities even though among congeners, suture geometry may differ in detail. We found this to be the case for nearly all the genera that we sampled (see Table 3).

Table 2. Calculation of conversion values (V) for suture lines taken from species of the genus Lytoceras (File S1 in the Supplementary Materials for this manuscript). The conversion values for each species are averaged to determine $\mathrm{V}$ for the genus.

\begin{tabular}{|c|c|c|c|c|}
\hline Genus & Species & $\mathbf{V}$ & Ave V & Std Dev \\
\hline \multirow{9}{*}{ Lytoceras } & L. subsequens & 1.95 & \multirow{9}{*}{1.75} & \multirow{9}{*}{ \pm 0.147} \\
\hline & M. submetrerum & 1.925 & & \\
\hline & E. phestum & 1.458 & & \\
\hline & L. fraasi & 1.864 & & \\
\hline & L. trilobeti & 1.840 & & \\
\hline & L. exoticum & 1.770 & & \\
\hline & L. serorugatum & 2.0 & & \\
\hline & L. julietti & 1.517 & & \\
\hline & L. alamadense & 1.421 & & \\
\hline
\end{tabular}


Table 3. Conversion values (V) for common genera of Jurassic and Cretaceous ammonites (File S1 of the Supplementary Materials for this manuscript). Single V values indicate cases where all species all of a genus cluster around this single V value. Double Vs indicate genera in which some species cluster around one value while other species are associated with the second $\mathrm{V}$ value; ${ }^{\circ}$ indicates a double $\mathrm{V} ;{ }^{*}$ indicates a triple $\mathrm{V}$.

\begin{tabular}{cc}
\hline GENUS & $\mathbf{V}$ \\
\hline Lytoceras & 1.75 \\
Gaudryceras & 2 \\
Tetragonites & 2 \\
Holcolytoceras & 1.2 \\
o Psiloceras & $1.55 ; 1.9$ \\
Dorsoplanites & 1.4 \\
Perisphinctes & 2 \\
Stephanoceras & 1.2 \\
Hildoceras & 1.4 \\
Harpoceras & 1.44 \\
Phylloceras & 1.3 \\
O Pachydiscus & $1.2 ; 2$ \\
Placenticeras & 2 \\
Scaphites & 1.65 \\
* Baculites & $1 ; 1.5 ; 2$ \\
\hline
\end{tabular}

As a result, in some systematically unresolved groups, e.g., primitive lytoceratids such as Psiloceras [39], disparate conversion values may be indicators of a need for further taxonomic revision.

Only three of the fifteen genera included in the study exhibited multiple conversion values (File S1 in the Supplementary Materials). However, at least two of these genera were previously thought to need additional taxonomic revision, such as some of the basal lytoceratids $[39,43]$ and possibly also Psiloceras. An even more well-known example of a systematically unresolved genus, Baculites, exhibited three conversion values, the most of any group in our study currently considered one genus. The appropriate systematic resolutions of certain Baculites from North America are unclear [45]. (It is important to note that all the Baculites included in our study were from the Western Interior Seaway of North America.) In addition, our method also assigned two conversion values to Pachydiscus, which, simply by virtue of having worldwide distribution, could also be a potential victim of generic undersplitting.

b. Shell Surface Flatness and the LLS Method. The issue of distortion from whorl curvature when tracing LLS suture elements from ammonites photographed in profile was ruled out as insignificant by a series of Kruskal-Wallis analyses. We tested genera with various degrees of lateral compression based on Raup's [46] coiling parameters and Raup and Chamberlain's [47] whorl expansion rates. This test was based on a process in which lateral lobes and saddles were counted in the LLS Method from sutures present on actual shell surfaces, and then repeating the process using profile photographs of these same shells (see File S2 in the Supplementary Marterials for this manuscript, for data).

Kruskal-Wallis was chosen over more conventional tests due to its allowance of small sample sizes-it was not possible to find a high number of usable photos from all genera included, especially Cadoceras. These data can be seen in Table 4. In Raup's system, shells with $S<1$ are the most laterally compressed and almost perfectly flat, e.g., oxyconic shells; ammonites with $\mathrm{S}>1$ are the least laterally compressed, e.g., cadiconic shells. Cadicones are an uncommonly small group of extremely rotund ammonites. Thus, our test examined genera representing a wide array of surface curvature, from flat to highly curved. Cadicones would only need be excluded if their roundness precluded presentation of the full lateral lobe (L) in profile, and therefore, additional conversion values for the 
highest-order umbilical lobes visible would need to be calculated. However, our tests demonstrated insignificance of any difference between flat (data from photographs) and curved data (data from shell surfaces) for the genus Cadoceras up to at least its subadult stage. We were unable to access a sample size of complete Cadoceras hemisutures that would be sufficient to determine the genus' conversion value, but there was no significant difference between curved- and flat-traced LLS data from either the expected conversion value, $V$, based on a small sample size (two) as well as the raw step counts, $N$.

Table 4. Kruskal-Wallis analysis for ammonite conches with $\mathrm{W}$-values from 0.2 to 0.5 . Mean $D f$ is the mean fractal dimension value for the given genus, in either the flat or curved data set. Coil profiles redrawn by KM from Raup [46]. Chi ${ }^{2}$ shows the difference between the categorical variables flat (traced) and curved (photographed). $p$ is the probability of a difference between the flat and curved medians; for $\mathrm{H} 0$ to be accepted, $p<\mathrm{Chi}^{2}$. When $p<\mathrm{Chi}^{2}$, there is no significant distortion by curvature.

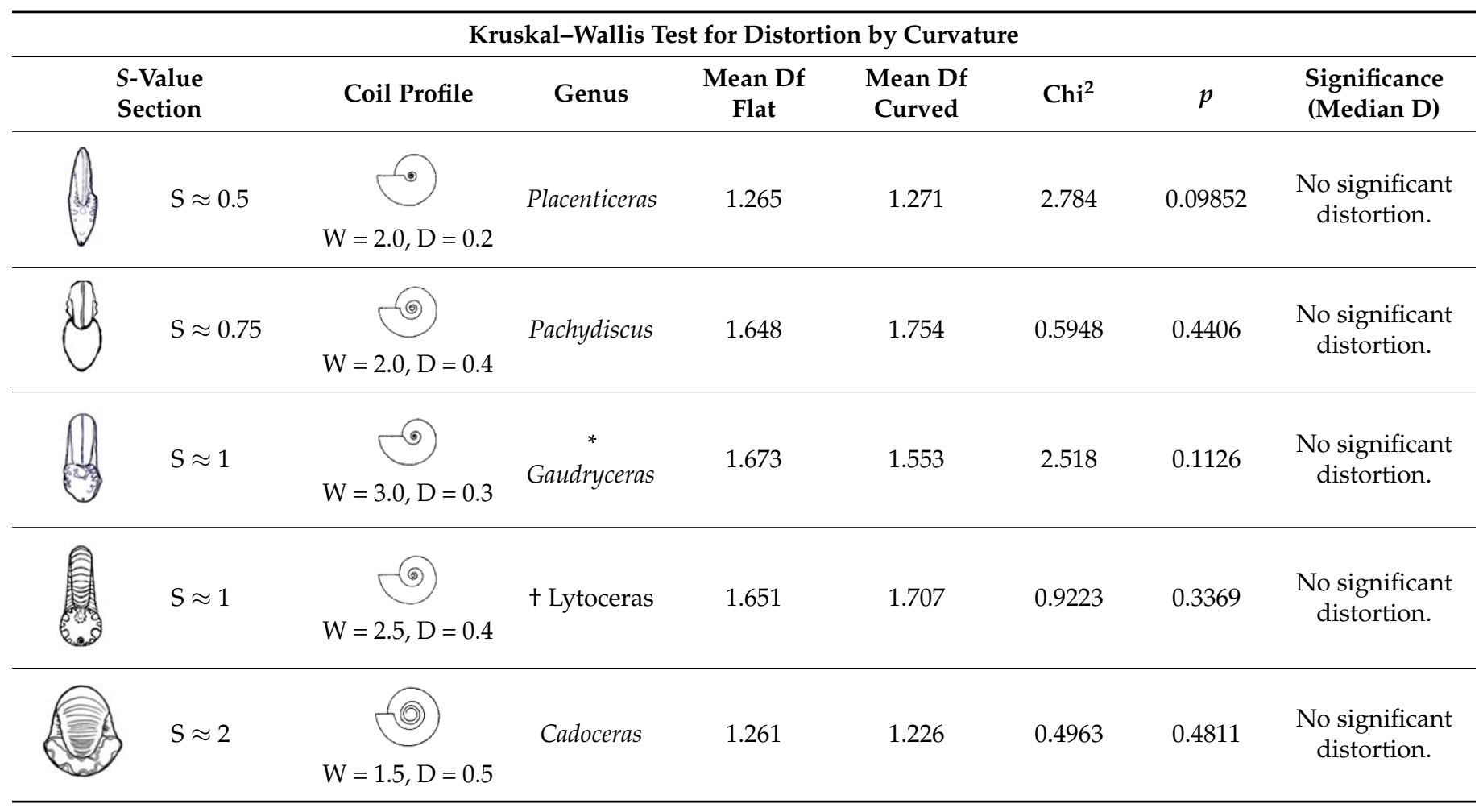

* Includes junior synonyms of Gaudryceras; + includes junior synonyms of Lytoceras.

\section{c. Ontogeny}

Studies of ammonite sutural ontogeny based on the Richardson Step Method of fractal analysis are few in number. Suture complexity varies directly with increased ontogeny, though the rate at which this occurs varies among ammonite genera $[10,48]$. Lutz and Boyajian [10] noted the lack of detailed ontogenetic sequences published for fractal dimension of sutures. Garcia-Ruiz et al. $[15,18]$ have used Richardson fractals but they did not account for the ontogenetic stage in which the sutures were measured, nor were they able to quantify the rate of change between sutures in the ontogenetic sequence for different lineages of ammonites [10]. The key problem here is that in shells exhibiting whorl overlap, which constitute the great majority of ammonite shell types, researchers only have access to the entire hemisuture on the outer whorl. On inner whorls, part of the hemisuture is covered by whorl overlap, as is the case with the specimen of Gaudryceras sacya illustrated in Figure 6. Whorl overlap precludes ontogenetic analysis of sutures in the inner whorls using the Richardson step method. This means that Richardson examinations of sutural ontogeny must involve a suite of shells representing different growth stages of a species in which complete hemisutures for different whorls (e.g., first, second, or third) 
are exposed in the last-formed part of different shells. However, in nearly all ammonite shell types, except perhaps some high-shouldered oxycones, the lateral lobe and saddle of inner whorls are not covered by whorl overlap, as is demonstrated in Figure 6B for G. sacya. The LLS Step Method we describe here thus provides a framework in which potentially the entire history of sutural ontogeny can be examined in well-preserved ammonite shells. Figure 6 shows an example of ontogenetic sequences of well over a whorl in length that derive from measurement on sutures in single shells with significant whorl overlap.

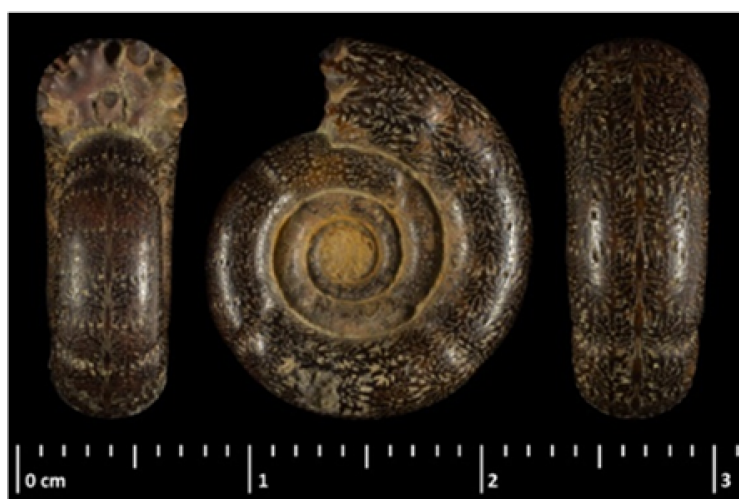

(A)

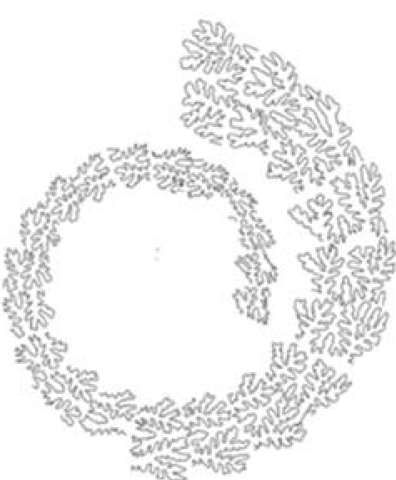

(B)

Figure 6. (A) Gaudryceras sacya Specimen MNHN-F-R00642 from Musee National d'Histoire Naturelle, Paris. (B) A tracing of MNHN-F-R00642 using only lateral lobe and saddle elements. Drawn by K.M.

\section{d. Preservation}

Sample size is a challenge for ammonite workers interested in sutures because an ideal degree of erosion is required in which the outer shell is removed but the fine details of the lobelets are still present on the specimen. If a shell is overly eroded, the complexity of the sutures will be simplified such that the fractal values may appear lower than typical for a given genus. While LLS cannot address this type of damage, it can be applied to shells that may otherwise be too imperfect for fractal or ontogenetic analysis using the Richardson hemisuture method. Broken ammonites, including steinkerns, are admissible for study via the LLS Method provided only that the lateral lobe and second saddle are intact. The condition of the remaining parts of a suture, whether missing, crushed, or distorted, is immaterial. Additionally, the LLS Method allows for fractal analysis of suture complexity in ammonites exhibiting a common taphonomic style of ectocochleate preservation. As a result of post-mortem waterlogging of their phragmocones [49-51], ammonite shells are commonly preserved lying on their sides, with the plane of shell symmetry roughly parallel to bedding surfaces. In this orientation, shells are subject to lateral compression resulting from taphonomic sediment compaction (Figure 7). Ammonites preserved in this orientation often exhibit lateral crushing but at the same time generally have intact $\mathrm{L}$ and $\mathrm{S}_{2}$ (Figure 7). Consequently, the sutures of even badly broken and crushed ammonites may often be studied as profitably as fully intact specimens via the LLS Method, as would be the case with the specimen of Lytoceras cornucopia shown in Figure 7. 


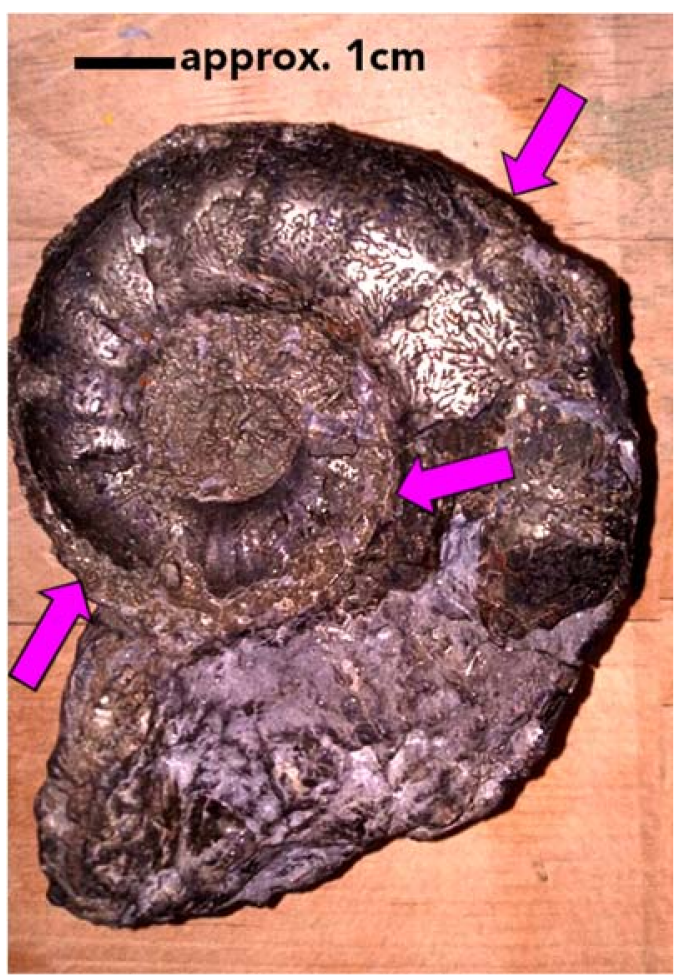

Figure 7. A Lytoceras cornucopia specimen which has undergone taphonomic lateral compaction and whose only fully intact suture elements are $\mathrm{L}$ and $\mathrm{S}_{2}$. The arrows indicate crushing of the external lobe (E) distalmost umbilical lobes $\left(\mathrm{U}_{1}\right)$.

\section{Concluding Remarks}

While the conversion of LLS data into the standard Richardson data is useful in some applications, such as for taxonomic issues, we emphasize that unconverted LLS step counts are internally consistent and as representative of sutural complexity as the counts obtained via the Richardson Method. LLS data can be used in any question to which Richardson data can be applied, and most noteworthy, the LLS approach allows researchers to expand study of sutural ontogeny to multi-whorled, overlapped shells, while at the same time widening the range of crushed and broken specimens whose sutures can be adequately examined. We suggest that the LLS Method is more broadly useful than the Richardson Method. Unlike Richardson D values, which normally have the fractal dimension boundaries of 1 and 2, the unconverted LLS dimensions in our data range in complexity 0.5 to 2.4 (y-axis in Figure 8). Ultimately, these differences relate to the fact that ammonite sutures only approximate true fractals, and thus do not follow the dimensional rules controlling true fractal geometries.

Comparing ammonite sutures based on their own respective $L_{\max }$ values rather than standard units of measurement (e.g., millimeters) that are arbitrary to them circumvents the issue of scale, specifically when dealing with ammonite sutures in virtual space, where scale is not easy or possible to determine. The use of fractional rule size (in place of finite rule sizes, such as a set length of millimeters) was first explored by Lutz and Boyajian [10] in order to measure the fractal dimensions of digitally generated ammonite sutures. While the role that scale plays in sutural complexity is not ruled out (due in large part to ontogeny), shell size alone does not directly vary with sutural complexity [10]. Additionally, in an ontogenetic sequence, the rule size increases slightly with each new suture that is measured, which ensures that the rule size is always proportional to the suture in question. As new sutures in the ontogenetic sequence are measured, the fractional rule size's proportional relationship to the suture does not change. By contrast, a rule size using millimeters is fixed and does not grow as the suture line widens, effectively shrinking in comparison to each subsequent suture. As noted by Perez-Claros et al. [13,14], a smaller rule size has 
greater resolution when measuring fractal dimension and a longer rule size is less resoluteusing a fractional rule size for each consecutive suture prevents the implementation of an inconsistent resolution over ontogeny.

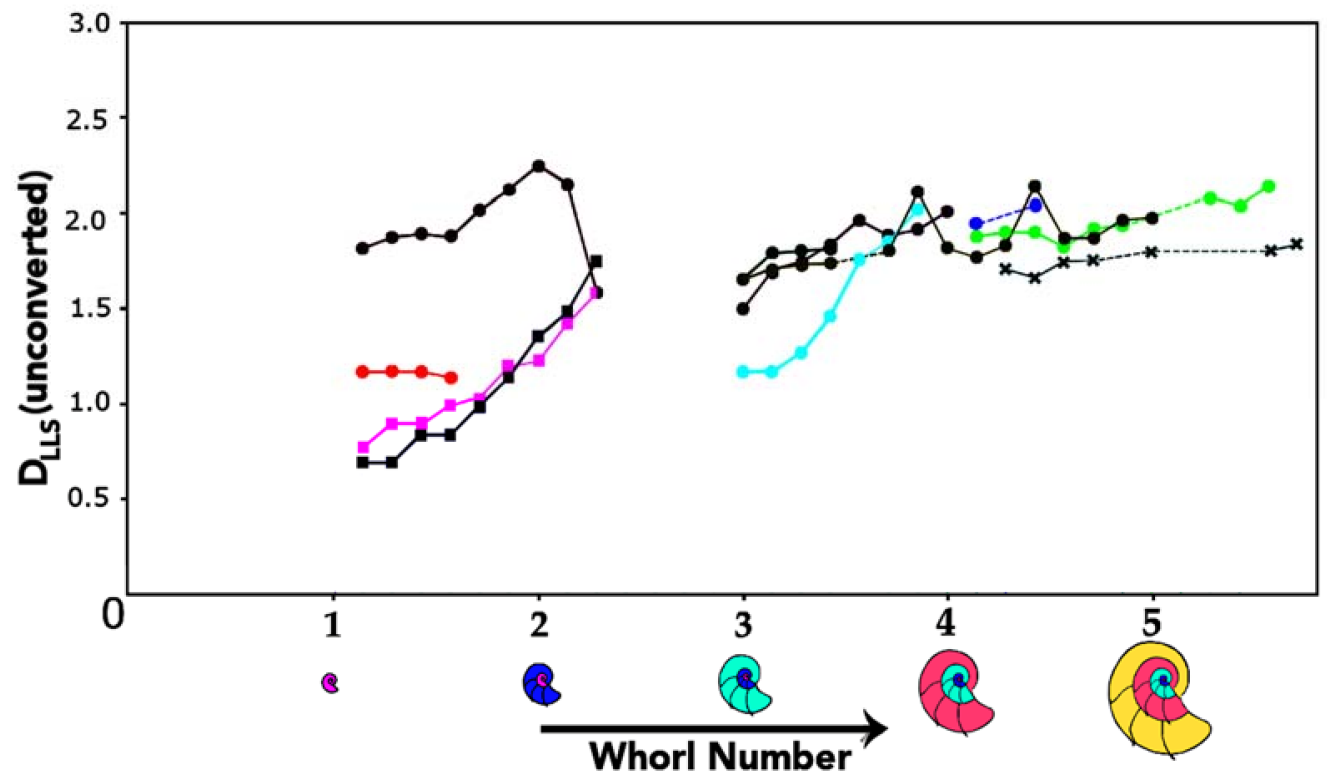

Figure 8. Plotted ontogenetic complexity of ammonite sutures using unconverted LLS data using [44]. Each symbol is for one suture and each curve is for sutures from a single shell. The $y$-axis shows the unconverted LLS fractal dimension. Squares indicate perisphinctids, circles indicate lytoceratids, and $\mathrm{x}$-shaped points indicate placenticeratids.

Supplementary Materials: The following are available online at https: / www.mdpi.com/article/10 .3390 / geosciences11110476/s1, File S1: step counts and sample medians, File S2: tests for distortion by shell curvature. References [52-58] are cited in the supplementary materials.

Author Contributions: K.M. devised the LLS Method and performed the suture tracing work. Both K.M. and J.A.C.J. wrote the paper. All authors have read and agreed to the published version of the manuscript.

Funding: This research received no external funding.

Institutional Review Board Statement: Not applicable.

Informed Consent Statement: Not applicable.

Data Availability Statement: The data for this research can be accessed in File S1 and File S2 of the Supplementary Materials. File S1 includes raw step counts, fractal dimensions, and boxplots comparing the sample medians. File S2 contains all fractal dimensions used in the Kruskal-Wallis analyses for distortion by curvature.

Acknowledgments: We thank R. Hoffmann (Ruhr-Universität Bochum) and the five anonymous reviewers of this paper for their suggestions which materially improved its presentation. We also thank R. Hoffmann for sharing numerous out-of-print publications containing ammonite suture tracings as well as photographed specimens. We thank D.R. Prothero (Natural History Museum of Los Angeles County) and C. Klug (University of Zürich) for their feedback on the explanation of our methods.

Conflicts of Interest: The authors declare no conflict of interest. 


\section{References}

1. Buckland, W. Geology and Mineralogy Considered with Reference to Natural Theology; Willian Pickering: London, UK, 1836.

2. Westermann, G.E.G. Form, structure and function of shell and siphuncule in coiled Mesozoic ammonoids. R. Ont. Mus. Life Sci. Contrib. 1971, 78, 1-39.

3. Mandelbrot, B.B. The Fractal Geometry of Nature; W.H. Freeman: New York, NY, USA, 1982.

4. Ward, P.D. Comparative shell shape distributions in Jurassic-Cretaceous ammonites and Jurassic-Tertiary Nautilids. Paleobiology 1980, 6, 32-43. [CrossRef]

5. Vicencio, R. Models for the Morphology and Morphogenesis of the Ammonoid Shell. Ph.D. Thesis, McMaster University, Hamilton, ON, Canada, 1973. Unpublished.

6. Guex, J. Associations virtuelles et discontinuités dans la distribution des espèces fossils: Un exemple intéressant. Bull. Soc. Vaud. Sci. Nat. 1981, 75, 179-197. [CrossRef]

7. Bayer, U. Pattern Recognition Problems in Geology and Paleontology; Springer: Berlin, Germany, 1985.

8. Damiani, G. Significato Funzionalle Dell'evoluzione dei setti e delle Line di Sutura dei Nautiloidi e Degli Ammonoidi. In Atti I Convengo Internationale: Fossili, Evoluzione, Ambiente, Pergola 1984; Pallini, G., Ed.; Tecnoscienza: Roma, Italy, 1986.

9. García-Ruiz, J.M.; Checa, A. A model for the morphogenesis of ammonoid septal sutures. Geobios 1993, 26, 157-162. [CrossRef]

10. Lutz, T.; Boyajian, G. Fractal Geometry of Ammonoid Sutures. Paleobiology 1995, 21, 329-342. [CrossRef]

11. Oloriz, F.; Palmqvist, P.; Perez-Claros, J.A. Shell features, main colonized environments, and fractal analysis of sutures in Late Jurassic ammonites. Lethaia 2007, 30, 191-204. [CrossRef]

12. Klug, C.; Hoffmann, R. Ammonoid septa and sutures. In Ammonoid Paleobiology, Volume I: From Anatomy to Ecology; Klug, C., De Baets, K., Kruta, I., Mapes, R., Eds.; Springer: Dordrecht, The Netherlands, 2015; pp. 45-90.

13. Pérez-Claros, J.; Palmqvist, P.; Oloriz, F. First and second orders of suture complexity in ammonites: A new methodological approach using fractal analysis. Math. Geol. 2002, 34, 323-332. [CrossRef]

14. Pérez-Claros, J.; Olóriz, F.; Palmqvist, P. Sutural complexity in Late Jurassic ammonites and its relationship with phragmocone size and shape: A multidimensional approach using fractal analysis. Lethaia 2007, 40, 253-272. [CrossRef]

15. Canfield, D.J.; Anstey, R.L. Harmonic analysis of cephalopod suture patterns. Math. Geol. 1981, 13, 23-35. [CrossRef]

16. Oloriz, F.; Palmqvist, P. Sutural complexity and bathymetry in ammonites: Fact or artifact? Lethaia 1995, 28, 167-170. [CrossRef]

17. Olóriz, F.; Palmqvist, P.; Pérez-Claros, J.A. Recent Advances in Morphometric Approaches to Covariation of Shell Features and the Complexity of Suture Lines in Late Jurassic Ammonites, with Reference to the Major Environments Colonized. In Advancing Research on Living and Fossil Cephalopods; Olóriz, F., Rodríguez-Tovar, F.J., Eds.; Springer: Boston, MA, USA, 1999. [CrossRef]

18. García-Ruiz, J.; Checa, A.; Rivas, P. On the origin of ammonite sutures. Paleobiology 1990, 16, 349-354. [CrossRef]

19. Hariri, K.E.; Bachnou, A. Describing Ammonite shape using Fourier analysis. J. Afr. Earth Sci. 2004, 39, 347-352. [CrossRef]

20. Jiang, J.; Plotnick, R.E. Fractal Analysis of the Complexity of United States Coastlines. Math. Geol. 1998, 30, 535-546. [CrossRef]

21. Reeside, J.B. A comparison of the genera Metaplacenticeras Spath and Placenticeras Meek. Shorter Contrib. Gen. Geol. 1926. [CrossRef]

22. Cobban, W.A. New Species of Baculites from the Upper Cretaceous of Montana and South Dakota. J. Paleontol. 1951, $25,817-821$. Available online: http:/ / www.jstor.org/stable/1299823 (accessed on 21 September 2021).

23. Cobban, W.A. Two New Species of Baculites from the Western Interior Region. J. Paleontol. 1958, 32, 660-665. Available online: http:/ / www.jstor.org/stable/1300784 (accessed on 21 September 2021).

24. Cobban, W.A. The Late Cretaceous Ammonites Scaphites Leei Reeside and Scaphites Hippocrepis DeKay in the Western Interior of the United States; United States Government Printing Office: Washington, DC, USA, 1969; 29p. [CrossRef]

25. Cobban, W.A. Baculites from the Lower Part of the Pierre Shale and Equivalent Rocks in the Western Interior. J. Paleontol. 1962, 36, 704-718. Available online: http:/ / www.jstor.org/stable/1301354 (accessed on 21 September 2021).

26. Schindewolf, O. On development, evolution, and terminology of ammonoid suture line. Bull. Mus. Comp. Zool. Harv. Coll. 1953, $112,217-237$.

27. Schindewolf, O. Studien zur Stammesgeschichte der Ammoniten. Lief 1. Ash. Akad. Wiss. Lit. Mainz Math.-Nat Kl 1960, 10, 639-743.

28. Schindewolf, O. Studien zur Stammesgeschichte der Ammoniten. Lief 3. Ash. Akad. Wiss. Lit. Mainz Math.-Nat Kl, 1965; 13, 139-238.

29. Cobban, W.A.; Jeletzky, J.A. A New Scaphite from the Campanian Rocks of the Western Interior of North America. J. Paleontol. 1965, 39, 794-801.

30. Kullmann, J.; Wiedmann, J. Significance of sutures in phylogeny of Ammonoidea. In The University of Kansas Paleontological Contributions; The University of Kansas: Lawrence, KS, USA, 1970; pp. 1-25.

31. Schlegelmilch, R. Die Ammoniten des Suddeutschen Lias; Gustav Fischer Verlag: Jena, Germany, 1976.

32. Schlegelmilch, R. Die Ammoniten des Suddeutschen Malms; Gustav Fischer Verlag: Jena, Germany, 1994.

33. Stevens, G. A revision of the Lytoceratinae (Subclass Ammonoidea) including Lytoceras taharoaense n. sp., Upper Jurassic, New Zealand. N. Z. J. Geol. Geophys. 1985, 28, 153-185. [CrossRef]

34. Lominazde, T.; Sharikazde, M.; Kvantaliani, I. Phylogeny and systematics of Perisphinctids as interpreted from suture ontogenies. Geobios 1993, 26 (Suppl. 1), 275-286. 
35. Kennedy, W.J.; Cobban. Campanian Ammonites from the Annona Chalk near Yancy, Arkansas. J. Paleontol. 1993, 67, 183-197. [CrossRef]

36. Kennedy, W.J.; Cobban, W.A.; Landman, N.H. Two species of Placenticeras (Ammonitina) from the Upper Cretaceous (Campanian) of the Western Interior of the United States. In American Museum Novitates; The American Museum of Natural History: New York, NY, USA, 1996.

37. Shevyrev, A.A. The development of the suture line in Mesozoic ammonoids and the terminology of its elements. Int. Geol. Rev. 1963, 5, 1659-1669. [CrossRef]

38. Joly, B. Aptian and Albian Phylloceratids (Ammonoidea) from the Vocontian Basin (SE France). Carnets Geol. 2008, CG2008 (M04), $1-60$.

39. Hoffmann, R. New insights on the phylogeny of the Lytoceratoidea (ammonitina) from the septal lobe and its functional interpretation. Rev. Paleobiol. 2010, 29, 1-159.

40. Ifrim, C.; Stinnesbeck, W.; Garza, R.R.; Ventura, J.F. Hemipelagic cephalopods from the Maastrichtian (late Cretaceous) Parras Basin at La Parra, Coahuila, Mexico, and their implications for the correlation of the lower Difunta Group. J. S. Am. Earth Sci. 2010, 29, 597-618. [CrossRef]

41. Galácz, A.; Kassai, P. New species and stratigraphic data on Lower Bajocian (Middle Jurassic) lytoceratids (Ammonoidea) from Lókút, Bakony Mts, Hungary. Paläontolog. Z. 2012, 86, 281-295. [CrossRef]

42. Dias-Canas, J.S.; Patarroyo, P. Vista de Pachydiscus del Campaniano Superior-Maastrichtiano Inferior de la formación Penderisco, cordillera occidental (Antioquia-Colombia) (unal.edu.co). Geol. Colomb. 2014, 39, 15-22.

43. Hoffmann, R.; Maisch, M. Systematics and phylogenetic position of the lytoceratid ammonite genus Holcolytoceras Spath, 1924 (Cephalopoda, Ammonoidea) from the Lower Pliensbachian of Europe. Neues Jahrb. Geol. Paläontolog. 2018, 288, 173-182. [CrossRef]

44. Hammer, Ø.; Harper, D.A.T.; Ryan, P.D. PAST: Paleontological Statistics Software Package for Education and Data Analysis. Palaeontol. Electron. 2001, 4,9.

45. Slattery, J.; Harries, P.J.; Sandness, A.L. A review of Late Cretaceous (Campanian and Maastrichtian heteromorphic ammonite paleobiology, paleoecology, and diversity in the Western Interior of North America. In Invertebrates: Spineless Wonders, 18th Annual Tate Conference; Cavigelli, J.P., Ed.; Tate Geological Museum, Casper College: Casper, WY, USA, $2012 ;$ pp. 76-93.

46. Raup, D.M. Geometric analysis of shell coiling: Coiling in ammonoids. J. Paleontol. 1967, 41, 43-65.

47. Raup, D.M.; Chamberlain, J.A. Equations for volume and center of gravity in ammonoid shells. J. Paleontol. 1967, 41, 566-574.

48. Boyajian, G.; Lutz, T. Evolution of biological complexity and its relation to taxonomic longevity in the Ammonoidea. Geology 1992, 20, 983-986. [CrossRef]

49. Weaver, J.S.; Chamberlain, J.A., Jr. Equations of motion for post-mortem sinking of cephalopod shells and the sinking of Nautilus. Paleobiology 1976, 2, 8-18. [CrossRef]

50. Chamberlain, J.A., Jr.; Weaver, J.S. Equations of motion for post-mortem sinking of cephalopod shells. Math. Geol. 1978, 10, 675-691. [CrossRef]

51. Chamberlain, J.A., Jr.; Ward, P.D.; Weaver, J.S. Post-mortem ascent of Nautilus shells: Implications for cephalopod paleobiogeography. Paleobiology 1981, 7, 494-509. [CrossRef]

52. Proceedings of the California Academy of Sciences Ser.3, Geology; California Academy of Sciences: San Francisco, CA, USA, 1897; Volume 1.

53. Natural History Museum: Suture Patterns within Subclass Ammonoidea I Natural History Museum. Available online: https:// natmus.humboldt.edu/exhibits/fossil-focus-exhibits/suture-patterns-within-subclass-ammonoidea (accessed on 21 September 2021).

54. Mikhailov, A.Y. Boreal Jurassic Ammonites (Dorsoplanitinae) and Zonal Subdivision of the Volgian Stage; Academy of Sciences of the USSR, Geological Institute: Moscow, Russia, 1963.

55. Maisch, M.; Hoffmann, R. Lytoceratids (Cephalopoda, Ammonoidea) from the Lower Posidonienschiefer Formation (Tenuicostatum Zone, Early Jurassic) of BadenWürttemberg (south-western Germany). N. Jb. Geol. Paläont. Abh. 2017. [CrossRef]

56. Muséum National d'Histoire Naturelle (MNHN). Consultation des Collections. Available online: https://science.mnhn.fr/ institution $/ \mathrm{mnhn} /$ list?collectionCode=f\&genus=Lytoceras (accessed on 9 November 2021).

57. Cobban, W.A.; Kennedy, W.J. Maastrichtian Ammonites Chiefly from the Prairie Bluff Chalk in Alabama and Mississippi. Memoir (Paleontol. Soc.) 1995, 44, 1-40. [CrossRef]

58. Paleontological Research Institution Digital Atlas of Ancient Life. Cadoceras sublaeve. Available online: https://www. digitalatlasofancientlife.org/vc/mollusca/cephalopoda/ammonoidea/ (accessed on 21 September 2021). 